\title{
Toxicity of Common Indoor Household Insecticides Registered in Florida'
}

\author{
Frederick M. Fishel ${ }^{2}$
}

\section{Background}

Insecticides are designed to kill insect pests, but, if used incorrectly, they may damage desirable plants and animals, including humans. Some pesticides are so highly toxic that very small quantities can cause illness or eye damage, burn the skin, or even cause death. Because common pesticides, such as those intended for household use, can irritate the skin, eyes, nose, or mouth, it is a good idea to understand the toxicity of household insecticides so you can follow practices designed to reduce exposure to people, pets, and other nontarget organisms. This document addresses the acute toxicity of common indoor household insecticide active ingredients registered in Florida and provides a table with mammalian toxicity values for each of these insecticides.

\section{Acute Toxicity}

The acute toxicity of a chemical refers to its ability to do systemic damage as a result of a one-time exposure to relatively large amounts of the chemical. A pesticide with a high acute toxicity may be deadly if even a very small amount is absorbed or ingested. The Environmental Protection Agency (EPA) designates signal words on a pesticide label to inform users of the toxicity level. The signal words on the label (Table 1) are based on the acute toxicity of the pesticide and are divided into four categories based on the amount that causes damage. Acute toxicity may be measured as acute oral (through the mouth), acute dermal (through the skin), and acute inhalation (through the lungs or respiratory system). For more information about signal words and pesticide labeling, please refer to https://edis.ifas. ufl.edu/pi137.

\section{Acute Toxicity Measures}

The commonly used term to describe acute toxicity is $\mathrm{LD}_{50}$. LD means lethal dose (deadly amount) and the subscript 50 means that the dose was acutely lethal to $50 \%$ of the animals to whom the chemical was administered under controlled laboratory conditions. The test animals, most commonly rats, mice, and/or rabbits, are given specific amounts of the chemical in either one oral dose, by a single injection, or dermally, and they are then observed for a specified time.

The lower the $\mathrm{LD}_{50}$ value, the more acutely toxic the pesticide-it takes less of it to cause harm. Therefore, a pesticide with an oral $\mathrm{LD}_{50}$ of $500 \mathrm{mg} / \mathrm{kg}$ would be much less toxic than a pesticide with an $\mathrm{LD}_{50}$ of $5 \mathrm{mg} / \mathrm{kg}$. $\mathrm{LD}_{50}$ values are expressed as milligrams per kilogram $(\mathrm{mg} / \mathrm{kg})$, which means milligrams of chemical per kilogram of body weight of the animal. Milligram (mg) and kilogram (kg) are metric units of weight. Milligrams per kilogram is the same measure as parts per million. To put these units into

1. This document is PI282, one of a series of the Agronomy Department, UF/IFAS Extension. Original publication date September 2019. Visit the EDIS website at https://edis.ifas.ufl.edu for the currently supported version of this publication.

2. Frederick M. Fishel, professor, Agronomy Department, and director, Pesticide Information Office; UF/IFAS Extension, Gainesville, FL 32611.

Use insecticides safely. Read and follow directions on the manufacturer's label.

The Institute of Food and Agricultural Sciences (IFAS) is an Equal Opportunity Institution authorized to provide research, educational information and other services

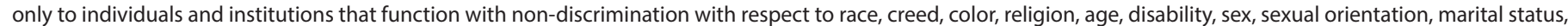

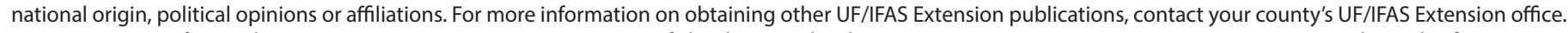
U.S. Department of Agriculture, UF/IFAS Extension Service, University of Florida, IFAS, Florida A \& M University Cooperative Extension Program, and Boards of County Commissioners Cooperating. Nick T. Place, dean for UF/IFAS Extension. 
perspective, $1 \mathrm{ppm}$ is analogous to 1 inch in 16 miles or 1 minute in 2 years.

For example, if the oral $\mathrm{LD}_{50}$ of the insecticide parathion is $4 \mathrm{mg} / \mathrm{kg}$, a dose of 4 parts of parathion for every million parts of body weight would be lethal to at least half of the test animals. As an example, the $\mathrm{LD}_{50}$ of caffeine is $150-200$ $\mathrm{mg} / \mathrm{kg}$, and the $\mathrm{LD}_{50}$ of table salt is about $3,000 \mathrm{mg} / \mathrm{kg}$.

$\mathrm{LD}_{50}$ values are generally expressed based on active ingredient. If a commercial product is formulated to contain 50 percent active ingredient, it would take two parts of the material to make one part of the active ingredient. In some cases, other chemicals mixed with the active ingredient for formulating the pesticide product may cause the toxicity to differ from that of the active ingredient alone. Each pesticide product label lists its common name under the active ingredient statement to identify what is in the product. Then, knowing the active ingredient(s), you may use Table 2 to determine the $\mathrm{LD}_{50}$ value of the product.

Another designation is $\mathrm{LC}_{50}$, which measures acute inhalation toxicity. LC means lethal concentration. Concentration is used instead of dose because the amount of pesticide inhaled in the air is being measured. $\mathrm{LC}_{50}$ values are measured in milligrams per liter. Liters are metric units of volume that are similar to a quart. The lower the $\mathrm{LC}_{50}$ value, the more toxic the pesticide.

\section{Additional Information}

National Pesticide Information Center (1-800-858-7378 or http://npic.orst.edu/).

Nesheim, O. N., F. M. Fishel, and M. A. Mossler. 2005. Toxicity of Pesticides. PI-13. Gainesville: University of Florida Institute of Food and Agricultural Sciences. http:// edis.ifas.ufl.edu/pi008 
Table 1. Acute toxicity measures and warnings.

\begin{tabular}{|c|c|c|c|c|c|}
\hline \multirow[b]{3}{*}{ Categories } & \multirow[b]{3}{*}{ Signal word } & \multicolumn{3}{|c|}{ Categories of acute toxicity } & \multirow[b]{3}{*}{ Oral lethal dose' } \\
\hline & & \multicolumn{2}{|c|}{$\mathbf{L D}_{50}$} & \multirow{2}{*}{$\frac{\text { LC }_{50}}{\text { Inhalation } \mathbf{~ m g / l}}$} & \\
\hline & & Oral mg/kg & Dermal mg/kg & & \\
\hline I Highly toxic & $\begin{array}{l}\text { DANGER, POISON (skull } \\
\text { and crossbones) }\end{array}$ & 0 to 50 & 0 to 200 & 0 to 0.2 & A few drops to a teaspoon \\
\hline II Moderately toxic & WARNING & 50 to 500 & 200 to 2,000 & 0.2 to 2.0 & $\begin{array}{l}\text { Over a teaspoon to one } \\
\text { ounce }\end{array}$ \\
\hline III Slightly toxic & CAUTION & 500 to 5,000 & 2,000 to 20,000 & 2.0 to 20 & Over one ounce to one pint \\
\hline IV Relatively nontoxic & $\begin{array}{l}\text { CAUTION (or no signal } \\
\text { word) }\end{array}$ & $5,000+$ & $20,000+$ & $20+$ & Over one pint to one pound \\
\hline
\end{tabular}

Table 2. Acute toxicity values for commonly used indoor household insecticides.

\begin{tabular}{|c|c|c|c|}
\hline Common name & Oral LD $_{50}(\mathbf{m g} / \mathbf{k g})^{1}$ & Dermal LD $_{50}(\mathbf{m g} / \mathbf{k g})^{1}$ & Inhalation LD Lo $_{50}(\mathrm{mg} / \mathrm{l})^{1}$ \\
\hline Abamectin & 221 & 330 & 2.2 \\
\hline Acetamiprid & $>2,000$ & $>2,000$ & $>3.5$ \\
\hline Allethrin, d-cis,trans allethrin & 685 & $>11,000$ & $>3.8$ \\
\hline Bifenthrin & 632 & $>2,000$ & 1.0 \\
\hline \multicolumn{4}{|l|}{ Bioallethrin (see d-cis,trans allethrin) } \\
\hline Boric acid & $>5,000$ & $>5,050$ & --- \\
\hline Cyfluthrin & 960 & $>2,000$ & 4.0 \\
\hline Cyhalothrin-gamma & $>5,000$ & $>5,000$ & $0.3-0.4$ \\
\hline Cyhalothrin-lambda & $>5,000$ & $>2,000$ & 0.06 \\
\hline Cypermethrin & 294 & $>2,000$ & $>2.02$ \\
\hline Deltamethrin & 2,613 & $>5,000$ & $>1.02$ \\
\hline Dichlorobenzene-para & 500 & $>2,000$ & $>6.0$ \\
\hline Dichlorvos & 25 & 59 & 15.0 \\
\hline Dinotefuran & $>2,000$ & $>2,000$ & $>2.07$ \\
\hline d-limonene & $>5,000$ & $>5,000$ & -- \\
\hline Esfenvalerate & 1,470 & $>2,000$ & 2.93 \\
\hline Fipronil & $>5,000$ & $>5,000$ & 5.16 \\
\hline Hydramethylnon & $>5,000$ & $>2,000$ & 2.9 \\
\hline Imidacloprid & $>4,820$ & $>2,000$ & 2.25 \\
\hline Imiprothrin & 1,800 & 2,000 & $>5.1$ \\
\hline Mineral oil & $>2,000$ & $>2,000$ & $>5$ \\
\hline Napthalene & 13,900 & $\mathrm{~N} / \mathrm{A}$ & $>340$ \\
\hline Permethrin & 1,030 & $>2,000$ & 25.7 \\
\hline Phenothrin & $>5,000$ & $>5,000$ & 10.4 \\
\hline Prallethrin & 640 & $>2,000$ & $0.66-0.86$ \\
\hline Propoxur & 50 & $>5,000$ & $>2.11$ \\
\hline Pyrethrins & $>2,000$ & $>2,000$ & $>2.11$ \\
\hline Pyriproxyfen & $>5,000$ & $>2,000$ & $>7.60$ \\
\hline Sumithrin (d-phenothrin) & $>10,000$ & $>10,000$ & $>2.10$ \\
\hline Tetramethrin & $>5,000$ & $>5,000$ & 5.63 \\
\hline
\end{tabular}

